\begin{tabular}{|c|c|c|}
\hline & Our Nature & $\begin{array}{l}\text { ISSN: 1991-2951 (Print) } \\
\text { ISSN: 2091-2781 (Online) }\end{array}$ \\
\hline $\begin{array}{l}\text { Vature Conservation \& } \\
\text { Health Care Council } \\
\text { Biratrogar, Nopol }\end{array}$ & Journal homepage: http://nepjol.info/index.php/ON & (c) ${ }_{\mathrm{BY}}(\mathrm{f})$ \\
\hline
\end{tabular}

\title{
On the Bayat (Turkey) rugs, motif stories, used dyeing plants and their ethnobotanical properties
}

\author{
Süleyman Arı ${ }^{*}$, Mustafa Kargığlu ${ }^{1}$ and Muhsin Konuk ${ }^{2}$ \\ ${ }^{1}$ Afyon Kocatepe University, Faculty of Science and Arts, \\ Department of Moleculer Biology and Genetics, 03200, Afyonkarahisar, Turkey \\ ${ }^{2} \ddot{U}$ sküdar University, Faculty of Engineering and Natural Sciences, \\ Department of Molecular Biology and Genetics, 34662, Istanbul, Turkey \\ *E-mail: slymanari@hotmail.com
}

\begin{abstract}
Bayat rugs weaved with different madders can be used without fading their colors almost 100 years. The study aimed to record how to get madder by traditional methods from local plants, give stories of rug motives and present an overview of the medicinal uses of dyes plants collected in Afyonkarahisar, Inner-West Anatolia, Turkey. The study was conducted in both 11 villages and downtown of Bayat borough of Afyonkarahisar in 2013-2014. A total 150 women, aged between 17-25, were interviewed and observations were photographed. The rugs are completely $100 \%$ sheep wool and strings for weaving prepared traditionally by special spinning methods. The used plants to obtain the madders were determined. It was understood that in early August and September, plants give better colors and tones. These plants have also been used for medicinal purposes by the locals. Bayat people get non-fading colors from 11 plants (Allium cepa L., Berberis crataegina L., Papaver rhoeas, Papaver somniferum L., Malva silvestris L., Morus nigra L., Cistus laurifolius L., Quercus ithaburensis Decne. subsp. macrolepis (Kotschy) Hedge et Yalt, Rubia tinctorum L., Juglans regia L., Indigofera tinctoria L.) belonged to ten families. The plant organs used are root, shell, cupula, leaf, young shoot, and aerial parts of the plants. A natural mud is also used as alum in this region that provides to create dark colors, and prevents mixing the colors. It also inhibits fading the colors in the rugs' texture. It was also recorded that different motives in Bayat Rugs have also interesting historical stories.
\end{abstract}

Key words: Madder, Wool Carpet, Design, Anecdote, Staining plants, MAPs

DOI: http://dx.doi.org/10.3126/on.v15i1-2.18790

Manuscript details: Received: 14.03.2017 / Accepted: 07.11.2017

Citation: Ari, S., M. Kargioglu and M. Konuk 2017. On the Bayat (Turkey) rugs, motif stories, used dyeing plants and their ethnobotanical properties. Our Nature 15(1-2): 19-25. DOI: http://dx.doi.org/10.3126/on.v15i1-2.18790

Copyright: ( ) Ari et al., 2017. Creative Commons Attribution - Non Commercial 4.0 International License.

\section{Introduction}

Turkey has a significant flora in the world having around 10.000 plant species with $30 \%$ endemic (Güner et al., 2000). Many plant species are used for medicinal purposes, tea, food, dye and crafts (Ar1 et al., 2014). The richness in Turkish flora made the people tend to develop getting natural dyes and almost 150 species have been used in obtaining natural dyes (Akan, 2007). It is assumed that their dyeing properties were discovered by chance and have been exploited since antiquity (Guarrera et al., 2005). Getting dyes from plants have been known since ancient times, approximately fifth century B.C. (Mert et al., 1992).

Dyeing has been mentioned in the Chinese 
literature as cited by Eyüboğlu et al. (1983). In the $10^{\text {th }}$ century, there was a source defining the various Byzantine arts; Byzantine painting of monks is "Schedula Diversarium Artium". Other sources are the "Divers Secrets Curieux", "Secretum Philosophorum", and "On the Properties Things" written in English. Between 1500 and 1856, there were more than five thousand books printed on dyeing (Wilson, 1982).

Synthetic coloring agents were discovered in the mid $-19^{\text {th }}$ century as historical turning point for dyeing. The use of plants in dyeing was very common in the $19^{\text {th }}$ century, then slowly began to lose their importance due to development of synthetic dyes.

Making style and the motives (figures) both in Turkish rugs and carpets are as old as Turkish civilization, and these features have transferred up to day. Since, caravan routes and trade remained in the hands of the Turks, they brought large quantities of dyeing plants and exported them to Europe until 1460s (Harmancioğlu, 1955).

The province of Afyonkarahisar is located in the inner-western part of the Aegean region of Anatolia and phytogeographically located on the transition zone between Irano-Turanian and Mediterranean regions. The area also has a high number of Euro-Siberian (Euxine) phytogeographic elements. Afyonkarahisar (Lat. $38^{\circ} 45^{\prime} \mathrm{N}$, Long. $30^{\circ} 32^{\prime} \mathrm{E}$; alt. $1034 \mathrm{~m}$ ) is adjacent to the provinces of Eskişehir, Kütahya, Konya, Isparta, and Uşak (Fig. 1). Although it is located in the Aegean region, it is similar to the climatic aspects of the region of Central Anatolia. It has semi-arid Mediterranean bioclimate with annual precipitation of $410-478 \mathrm{~mm}$. As vegetation, a variety of plant species as well as cedar and larch can be seen with a combination of relict species (Ar1, 2014). The damage in the surrounding areas has transformed the study area into anthropogenic steppe areas (Acar et al., 2012).

The study area (Bayat environ, a borough of Afyonkarahisar) is surrounded by Çal Mountains and Hendi Baba Mountains in north, Asar and Bey Mountains in west, Kazankaya Mountains in south, and Mekecik and Çal Mountains in southeast. In the past, the surrounding hills and high mountains were covered with rich forests but along with time was destroyed and today the newly planted "Mekecik woods" forest is available.

Income of the population relies on agriculture, livestock and rug weaving in Bayat region. The income from agricultural products; barley, wheat and poppy take first place. Only $1 / 3$ of the total area in Bayat is arable case. There is extensive pasture for livestock. Livestock carried out in mountainous areas and sheep, angora goats, Brown swiss and Bos taurus are grown in these areas. The average monthly income of the person who is weaving rugs is $\$ 200-250$. For getting the dyes from the plants and weaving activities, 12 residential areas viz., Akpinar, Aşağı Çaybelen, Derbent, Eskigömü, Sağırhimrallı, İnpinar, Mallıca, Kuzuören, Muratkoru, Çukurkuyu, Yukançaybelen, and town of Bayat were scheduled.

Bayat rugs have special motifs and each rug motif weaved has a different story. Their stories reach out to Phrygians; these stories were transferred by generations as an element of the culture of the locals (Urfal1, 2012). This study was aimed to record of obtaining madders from plants by using traditional methods, the stories of the motives (figures) used in the rugs, and medicinal uses of these dye plants by locals.

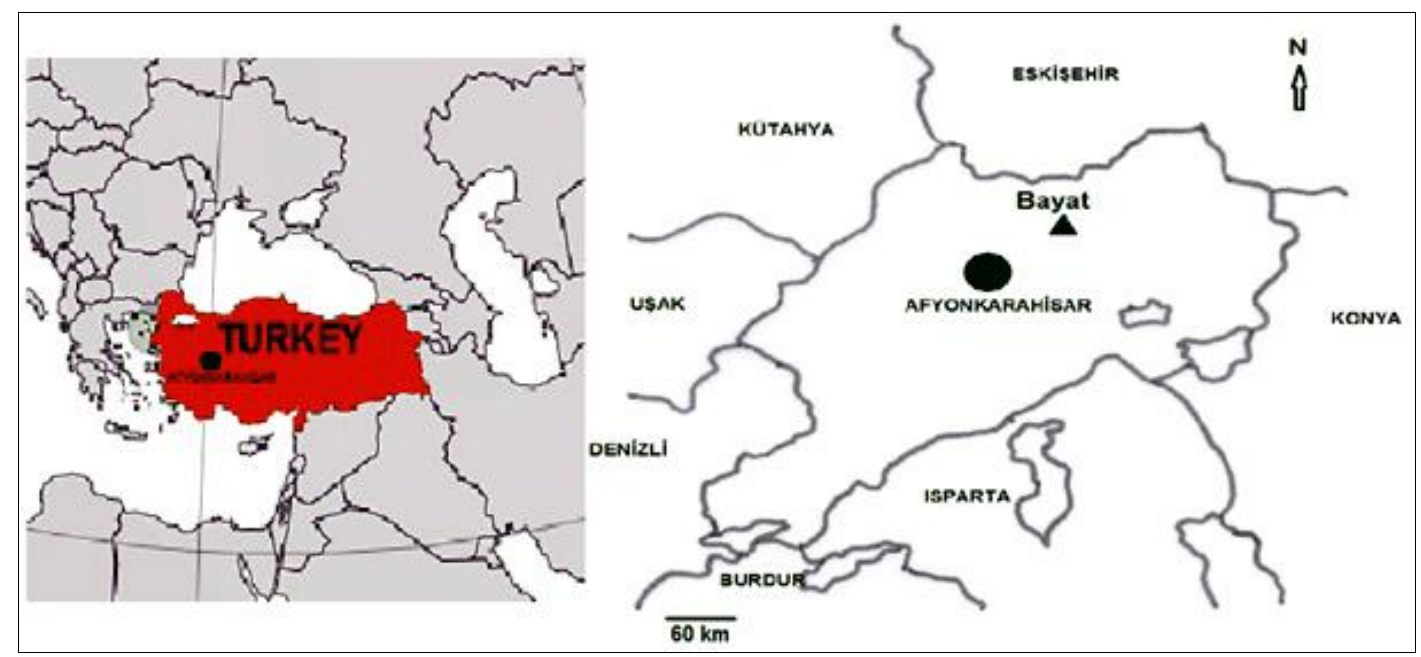

Figure 1. The map of study area. 


\section{Materials and methods Data collection}

The informants engaged to get madder and weaving, aged between 17-25, exactly 150 people (35 primary schools and 115 high school graduates), were interviewed and observations were photographed in 2013-2014. Interesting stories of plant motifs from past to present and medicinal uses of the dyeing plants were compiled from informants.

The plants were collected in the study area in early August and September to obtain better color and shades. Dye plants were identified by using "Flora of Turkey and the East Aegean Islands" (Güner et al., 2000). The plant samples were added to and kept in Afyon Kocatepe University Herbarium (AKUH).

Hundred percents sheep wool rugs were being used in the region. Locals obtained wool thread with the help of spindle (Fig. 2). The resulting yarn was boiled with plant(s) for 2-3 hours and cooled down (Fig. 3); the ropes were then hanged under sunlight for a day. This process increased the quality of coloring process of the strings (Figs. 4, 5) and then fine rugs were weaved (Fig. 6).

\section{Results \\ Motif stories}

Bayat rugs have different and special motives (Fig. 7). Each motif weaved has a different story behind it. The origin of the stories goes back to Phrygians time, and they were transferred as cultural elements from generation to generation. They have specific names such as Hayatağacı, Otağ, Avşargüzeli, Bıtıraklı, Ejder, Asarcık, Bindallı, Seleser, Saçbağlı, Muskalı, Körçiçekand Başakl1. The figures embroidered in Bindallı rugs symbolizes the wish that the newlyweds would have a tree which has thousands of roots and branches. Bindal in Turkish means thousand of branches or roots. These rugs are given as wedding present by bride's or groom's mother. Plane tree is special to Turks and has a mythological symbol. It reflects the splendor and/or life tree (Hayatağacı in Turkish), and this represents the Sultan's tent which is called Otağ. It also shows the emphasis of women in Turkish society. In traditional Turkish customs, teenage girls cannot easily tell their parents when they want to get married. However, they imply their desire by weaving a motif called Ciga which brides put on. The rug represents this motif is

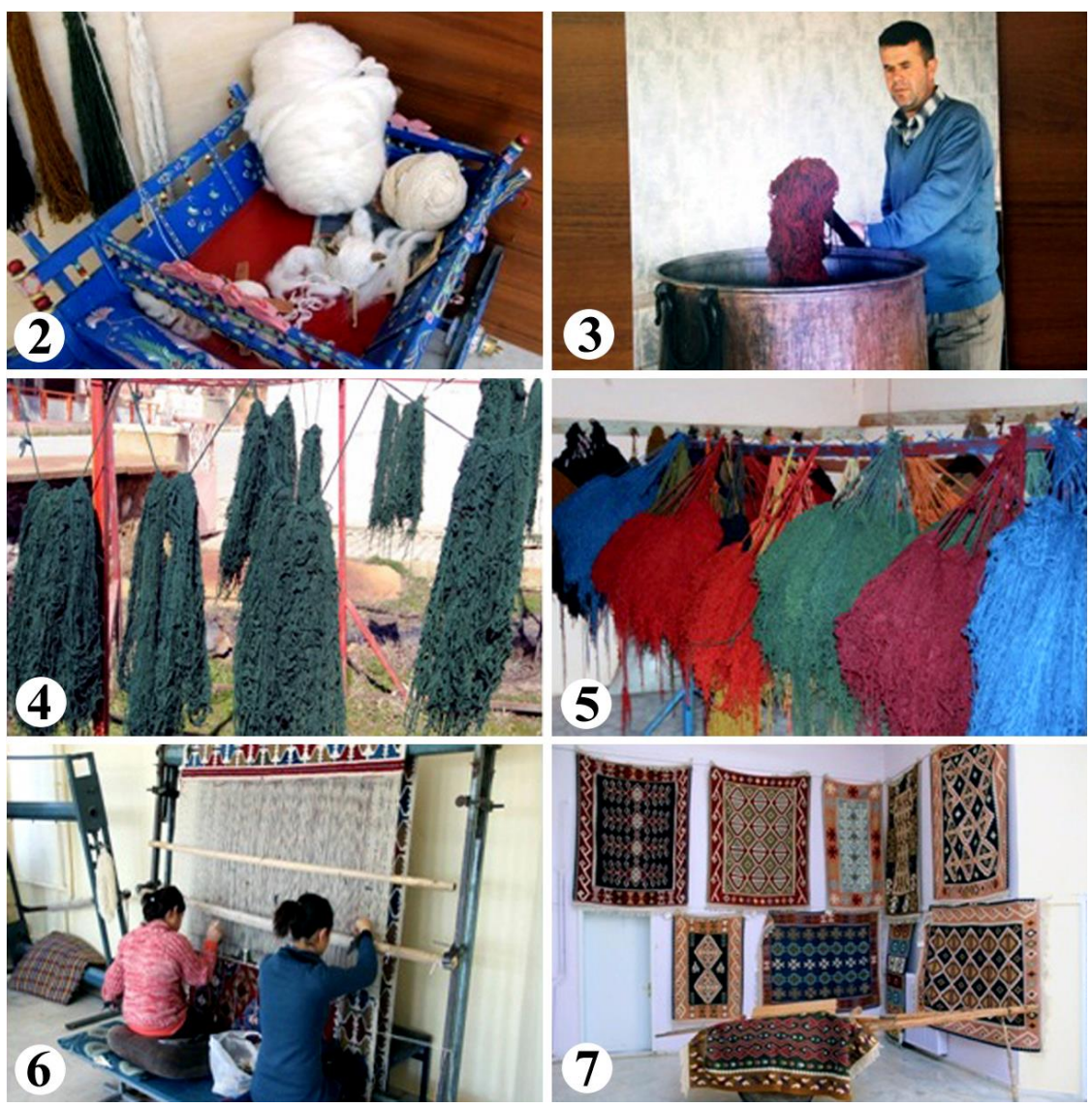

Figures 2. Sheep wool and obtained string by using wooden spindle 3. Plant parts boiled with the ropes to dye 4. Yarns are cooled down and left under the sunlight for one day 5. Different colored of wool yarns 6. The rug weaving process by teenage girls 7 . Bayat rug weaved by madder obtained from local plants. 
called Saçbağlı (tied hair). A Turkish lady who sent her husband to army pictures her longing, yearning and fears on the rug she weaves. This rug is called Seleser (seleser means soldier in Turkish). If she receives terrible news about her husband, it is supposing that she loses her eyesight and the rug remains unfinished. The rug is called Körçiçek (blind flower) to express the love and yearning of that lady. When ladies weave the motif to show the importance of agriculture and earth on the rug, this is called as Başaklı (spiked). Spike or ear of grain symbolizes the abundance, fertility, increase, blessing, and rain in Turkish custom. Bittrakl (with cocklebur) motif indicates the feeling of a young bride's unpleasant feelings for her mother-in-law. Dragon, a mythological creature, was the master of air and water. It was believed that dragon brought rich spring rains. The rug having dragon motif is named as Ejder (dragon) by the locals. Amulet is written by Hodjas and worn by the people and it is believed in protecting its owner from dangers with magical and religious powers. The rug that has the figure of amulet is called Muskalı (with Amulet). In the time of Seljuk state, a beautiful lady came to Bayat and she had a legendary beauty. Since that time everyone has been talking about her beauty and this lady was embroidered on the rug. This rug is named as Avşar güzeli (Avşar beauty, Avşar is one of the biggest Turkish tribes).

\section{Dyeing plants for Bayat Rugs}

The Latin and local names, used parts and colors obtained from 11 plants belonging to 10 families are listed according to the families' alphabetical order (Table 1). The represented families are: Amaryllidaceae (1 sp), Berberidaceae (1 sp), Cistaceae (1 sp), Fabaceae (1 sp), Fagaceae (1 $\mathrm{sp})$, Juglandaceae (1 sp), Malvaceae (1 sp), Moraceae (1 sp), Rubiaceae (1 sp) and Papaveraceae $(2 \mathrm{sp})$. The plant parts used to get madder are root, shell, cupula, leaf, young shoot and aerial organs. Their colors are not easily fading and lasting very long time ( 100 years) since a natural mud is used as alum. This natural mud provides dark colors, and prevents the mixing the colors during both weaving and usage. It also inhibits fading the colors in the rugs' texture.

\section{Ethnobotanical uses of the dyeing plants}

The plants used as dyeing source in the study area are also used for their medicinal and other benefits. Allium cepa is used for getting rid of the mild epidemical infections in Bayat district. The leaves of Berberis crataegina are effective for preventing kidney stones when they are consumed 15-20 days as salad. Their fruit is consumed directly. Papaver rhoeas and $P$. somniferum are taken for cold and as sedative. Malva sylvestris is consumed in the form of food after roasting in oil. Morus nigra is eaten directly or as marmalade made from fruit and used for infection and aphthae. Cistus laurifolius is not only used for dyeing but also used for both digestive and heart failure problems. Its roots, leaves and shoots are boiled in water to drink. Quercus ithaburensis subsp. macrolepis is used in handicrafts. Juglans regia is used for skin disorders and in handicrafts.

Table 1. The plants used to get mader in Bayat (Afyonkarahisar) (* Imported from India)

\begin{tabular}{|c|c|c|c|c|}
\hline Taxa / Voucher numbers & Local name & Family & Part uses & Colours \\
\hline Allium сера L. /AKUH -1023 & Soğan & Amaryllidaceae & Shell & Bright yellow \\
\hline Berberis crataegina DC./AKUH-1112 & Karamık & Berberidaceae & Root & Olive-green \\
\hline Papaver rhoeas L./AKUH-1045 & Gelincik & Papaveraceae & Flower & Leaden \\
\hline Papaver somniferum L./AKUH-1073 & Haşhaş & Papaveraceae & Leaf & Plato \\
\hline Malva silvestris L./AKUH-1034 & Ebegümeci & Malvaceae & Leaf & Green \\
\hline Morus nigra L./AKUH-1021 & Dut & Moraceae & Fruit & Yellow \\
\hline Cistus laurifolius L./AKUH-1105 & Pinar & Cistaceae & $\begin{array}{l}\text { Leaf and young } \\
\text { shoot }\end{array}$ & $\begin{array}{l}\text { Yellow and } \\
\text { green shades }\end{array}$ \\
\hline $\begin{array}{l}\text { Quercus ithaburensis Decne. subsp. } \\
\text { macrolepis (Kotschy) Hedge et } \\
\text { Yalt./AKUH-1087 }\end{array}$ & $\begin{array}{l}\text { Palamut } \\
\text { kupulaları }\end{array}$ & Fagaceae & Acorn caps & $\begin{array}{l}\text { Black, yellow } \\
\text { peas and shades }\end{array}$ \\
\hline Rubia tinctorum L./AKUH-905 & $\begin{array}{l}\text { Köpek üzümü } \\
\text { (BoyalıkOtu) }\end{array}$ & Rubiaceae & Root & Red and shades \\
\hline Juglans regia L./AKUH-1057 & Cevizkabuğu & Juglandaceae & Shell & $\begin{array}{l}\text { Brown and } \\
\text { shades }\end{array}$ \\
\hline *Indigofera tinctoria L./AKUH-1043 & Çivitotu & Fabaceae & $\begin{array}{l}\text { Above ground } \\
\text { organs }\end{array}$ & Blue and shades \\
\hline
\end{tabular}




\section{Discussion}

Bayat rugs keep their color for hundred years due to both plants and process employed. The plants (11 taxa) belong to ten families give special colors to the Bayat Rugs. The stories of motives are special for this region and encourage sustaining traditional rug weaving. It also provides an income for the local people. Some of dye plants mentioned in this study have been used for dyeing and other purposes in Turkey and other countries. Özgökçe and Yilmaz (2003) listed 50 taxa for East Anatolia, while Doğan et al. (2004) named 123 taxa for the whole Turkey, and some of them are endemic species. Several genera of dye plants Euphorbia, Rhamnus etc., are common in both Italy and Turkey (Guarrera, 2006). In the past, dye plants were important in Abruzzo and Calabria (Italy). Before the importation of Indigofera tinctoria, "pastel", furnished the blue shades given its ready availability alongside roads, in meadows and uncultivated fields and built-up areas (Tammaro, 1984). In Scanno village, warm solutions of ashes from the fireplace were used to fix the color of madder from Rubia tinctorum (Savo et al., 2013). Dyeing of fish nets obtained by a decoction of Pinus spp. bark was indicated as "zappino" or "zappinu", and the same name occurred in Sardinia, Campania and Sicily (Guarrera, 2006; Savo and Caneva, 2009). Juglans regia, Morus nigra and Quercus ithaburensis subsp. macrolepis in Bayat gives brown, yellow, black and shade colors. Hayta et al. (2014) used as a dyeing agent for black wool from Juglans regia, opaque olive yellow to dye wool from Morus nigra, very dark color from Quercus cerris.

The plants used as dyeing source in the study area are also used for their medicinal benefit as well. It is used for cicatrizing, rheumatism, asthma, cancer, diuretic, hypertension, fungal infection, headache, analgesic, bronchitis (Allabi et al., 2011), cough treatment, furuncles, influenza (Camejo-Rodrigues et al., 2003; Allabi et al., 2011), the leaves of Berberis crataegina are effective for preventing kidney stones when they are consumed 15-20 days as salad and its fruits is consumed directly in study area. It is used for kidney stones and the treatment of liver disease (Ar1 et al., 2014), also consumed to treat diarrhea, infused in boiling water and 2-3 cups are drunk daily as an antidiabetic tea (Kargioğlu et al., 2010). In Bayat district, Papaver rhoeas and P. somniferum are taken for cold and as sedative. In other studies, it is consumed as tranquilizer (Allabi et al., 2011), antitussive, sedative (Cakilcioglu et al., 2011), anti-cough (Pollio et al., 2008), red spots on body (Polat and Sat1l, 2012). While Malva sylvestris is consumed in the form of food after roasting in oil for digestive problems in our survey, it is also used for abscess, hematomas, inflammations, joint pains (Koyuncu et al., 2010), anti-inflammatory, for infertility, urinary inflammations (Polat et al., 2013), as antitussive, colds and flu, hemorrhoids (Özcan, 2003). Morus nigra is eaten directly or as marmalade made from fruit and used for infection and aphthae by local people. It is also used for anemia (Özcan, 2003; Orhan et al., 2009); the ripe fruit is rub on the lips of children to treat herpes (Camejo-Rodrigues et al., 2003); used for eczema, hepatitis (Hayta et al., 2014), diabetes disease, oral wounds (Koca and Yildırımli, 2010) and cholesterol (Polat and Sat1l, 2012). The leaves and shoots of Cistus laurifolius are boiled in water to drink and used for digestive problems. It is reported that it is used for diabetes (Polat and Sat11, 2012). While Quercus ithaburensis subsp. macrolepis is used in handicrafts in Afyonkarahisar, it is used to cure wound (Hayta et al., 2014). Quercus cerris is used for diabetes mellitus (Hayta et al., 2014), inflammation (Polat et al., 2013), astringent, dermatitis, hemorrhoid, and stomach ulcer (Öztürk and Ölçücü, 2011). Juglans regia in our study area benefits in skin disorders and in handicrafts, in the other studies, this is used for cardiac disorder, high cholesterol, antifungal, anti-lubrication, cholesterol, diabetes, hemorrhoids, psoriasis, respiratory tract problem antibacterial, anti-inflammatory, antiseptic, astringent, depurative, purgative, rheumatism, uterine disorders, skin disorders (Öztürk and Ölçücü, 2011; Hayta et al., 2014) and antifungal (Polat and Sat1l, 2012).

In the study area there is a natural mud which provides dark color, and prevents the mixing of the colors obtained from plants. This mud also prevents the fading of colors, but in our knowledge there is no information about natural mud.

As conclusion, the information obtained from this study is expected to help in protecting and sustaining the knowledge to get madder, rug weaving, mythological motives and medicinal uses of these plants. The verbal knowledge transferred from generation to generation is aimed to be recorded for next generations. 


\section{Acknowledgements}

We express our thanks to the Coordination Unit of Scientific Research Projects at Afyonkarahisar Kocatepe University for financial support. We specially thank local communities for sharing their knowledge and experiences. Our special thanks also due to Dr. H. Shazly (Swansea-UK) for checking its English.

\section{References}

Acar, H., A. Serteser and M. Kargioğlu 2012. Afyonkarahisar'daki Jipsli Topraklar ile Bitki Örtüsü Ilişkisi. AKU Journal of Science 12: 122.

Akan, M. 2007. Bazı Bitkiler ile Renklendirilmiş İlmelik Yün Halı İplerinde Oluşan Mukavamet Farklarının Tespiti Üzerine Bir Araştırma. Gazi Üniversitesi Endüstriyel Sanatlar Eğitim Fakültesi Dergisi 21: 98-116.

Allabi, A.C., K. Busia, V. Ekanmian and F. Bakiono 2011. The use of medicinal plants in self-care in the Agonlin Region of Benin. Journal of Ethnopharmacology 133: 234-243.

Ar1, S. 2014. Ethnobotanical properties of plants used by people in Afyonkarahisar and around. Department of Molecular Biology and Genetics, University of Afyon Kocatepe, Turkey. (Ph.D. Thesis)

Arı, S., Kargığlu, M. Temel and M. Konuk 2014. Traditional Tar production from the Anatolian Black Pine (Pinus nigra Arn. subsp. pallasiana (Lamb.) Holmboe var. pallasiana) and its uses in Afyonkarahisar, Central Western Turkey. Journal of Ethnobiology and Ethnomedicine 10: 29.

Cakilcioglu, U., S. Khatun, I. Turkoglu and S. Hayta 2011. Ethnopharmacological survey of medicinal plants in Maden (Elazig-Turkey). Journal of Ethnopharmacology 137: 469-486.

Camejo-Rodrigues, J., L. Ascensao, M.A. Bonet and J. Valles 2003. An ethnobotanical study of medicinal and aromatic plants in the Natural Park of "Serra de Sao Mamede" (Portugal). Journal of Ethnopharmacology 89: 199-209.

Doğan, Y., S. Başlar, H. Mert and G. Ay 2004. Plants used as natural dye sources in Turkey. Economic Botany 57: 442-453.

Eyüboğlu, Ü., D. Okaygün and F. Yaras 1983. Doğal Boyalarla Yün Boyama. Özkur Basımevi Istanbul. $137 \mathrm{p}$.

Guarrera, P.M. 2006. Household dyeing plants and traditional uses in some areas of Italy. Journal of Ethnobiology and Ethnomedicine 2: 9.

Guarrera, P.M., G. Forti and S. Marignoli 2005. Ethnobotanical and ethnomedicinal uses of plants in the District of Acquapendente (Latium, Central Italy). Journal of Ethnopharmacology 96(3): 429-444.

Güner, A., N. Özhatay, T. Ekim and K.H.C. Başer 2000. Flora of Turkey and the East Aegean Islands. Vol. 11. Edinburgh: Edinburgh University Press.

Harmancıŏglu, M. 1955. Türkiye'de Bulunan Önemli Bitki Boyalarından Elde Olunan Renklerin Çesitli Müessirlere Karsı Yün Üzerinde Haslık Dereceleri. Ankara Üniversitesi Basımevi, Ankara.

Hayta, Ş., R. Polat and S. Selvi 2014. Traditional uses of medicinal plants in Elazığ (Turkey). Journal of Ethnopharmacology 54: 613-623.

Kargıoğlu, M., S. Cenkci, A. Serteser, M. Konuk and G. Vural 2010. Traditional uses of wild plants in the Middle Aegean Region of Turkey. Journal of Human Ecology 38: 429-450.

Koca, A.D. and S. Yıldırımlı 2010. Ethnobotanical properties of Akçakoca District in Düzce (Turkey). Hacettepe Journal of Biology and Chemistry 38: 63-69.

Koyuncu, O., Ö.K. Yaylac1, D. Öztürk, İ.P. Erkara, F. Savaroğlu, Ö. Akcoşkun and M. Ardıç 2010. Risk categories and ethnobotanical features of the Lamiaceae taxa growing naturally in Osmaneli (Bilecik/Turkey) and environs. Biological Diversity and Conservation 3: 31-45.

Mert, H.H., Y. Doğan and S. Başlar 1992. Doğal Boya Eldesinde Kullanılan Bazı Bitkiler. Ecology 5: 14.

Orhan, N., M. Aslan, S. Hosbas and O.D. Deliorman 2009. Antidiabetic effect and antioxidant potential of Rosa Canina fruits. Pharmacognosy Magazine 5: 309-315.

Özcan, M. 2003. Antioxidant activities of Rosemary, Sage and Sumac extracts and their combinations on stability of natural Peanut oil. Journal of Medicinal Food 6: 267-270.

Özgökçe, F. and I. Yilmaz 2003. Dye plants of East Anatolia region (Turkey). Economic Botany 57: 454-460.

Öztürk, F. and C. Ölçücü. 2011. Ethnobotanical features of some plants in the District of Şemdinli (Hakkari-Turkey). International Journal of Academic Research 3: 120-125.

Polat, R. and F. Sat1l 2012. An ethnobotanical survey of medicinal plants in Edremit Gulf (BalıkesirTurkey). Journal of Ethnopharmacology 139: 626-641.

Polat, R., U. Cakilcioglu and F. Satıl 2013. Traditional uses of medicinal plants in Solhan (Bingol-Turkey). Journal of Ethnopharmacology 148: 951-963. 
Pollio, A., A. Natale, E. Appetiti, G. Aliotta and A. Touwaide 2008. Continuity and change in the mediterranean medical tradition: Ruta spp. (Rutaceae) in Hippocratic medicine and present practices. Journal of Ethnopharmacology 166: 469-482.

Savo, V. and G. Caneva 2009. Ricerche Etnobotaniche in Costiera Amalfitana: Gli Usi Marittimi. Informatore Botanico Italiano 41: 3-11.

Savo, V., A. La Rocca, G. Caneva, F. Rapallo and L. Cornara 2013. Plants used in artisanal fisheries on the Western Mediterranean Coasts of Italy.
Journal of Ethnobiol. and Ethnomedicine 9: 9.

Tammaro, F. 1984. Flora Officinale d'Abruzzo Chieti: Centro Servizi Culturali. Giunta Regionale d'Abruzzo.

Tita, I., G.D. Mogosanu and M.G. Tita 2009. Ethnobotanical inventory of medicinal plants from the South-West of Romania. Farmacia 57: 141-156.

Urfal1, A. 2012. History of Bayat (in Turkish). Bayat Belediyesi, Afyonkarahisar.

Wilson, K.A. 1982. History of Textiles. Westview Press/Boulder, 346S., Colorado, U.S. 